Int. J. Dev. Biol. 53: 1317-1327 (2009)

doi: $10.1387 /$ ijdb.072414es

\title{
Planarian regeneration: achievements and future directions after 20 years of research
}

\author{
EMILI SALÓ* JOSEP F. ABRIL, TERESA ADELL, FRANCESC CEBRIÀ, KAY ECKELT, \\ ENRIQUE FERNÁNDEZ-TABOADA, METTE HANDBERG-THORSAGER, MARTA IGLESIAS, \\ $M^{a}$ DOLORES MOLINA and GUSTAVO RODRÍGUEZ-ESTEBAN
}

Departament de Genètica, Facultat de Biologia and Institut de Biomedicina de la Universitat de Barcelona (IBUB), Barcelona, Catalunya, Spain

\begin{abstract}
Planarians can undergo dramatic changes in body size and regenerate their entire body plan from small pieces after cutting. This remarkable morphological plasticity has made them an excellent model in which to analyze phenomena such as morphogenesis, restoration of pattern and polarity, control of tissue proportions and tissue homeostasis. They have a unique population of pluripotent stem cells in the adult that can give rise to all differentiated cell types, including the germ cells. These cellular characteristics provide an excellent opportunity to study the mechanisms involved in the maintenance and differentiation of cell populations in intact and regenerating animals. Until recently, the planarian model system lacked opportunities for genetic analysis; however, this handicap was overcome in the last decade through the development of new molecular methods which have been successfully applied to planarians. These techniques have allowed analysis of the temporal and spatial expression of genes, as well as interference with gene function, generating the first phenotypes by loss or gain of function. Finally, the sequencing of the planarian genome has provided the essential tools for an in-depth analysis of the genomic regulation of this model system. In this review, we provide an overview of planarians as a model system for research into development and regeneration and describe new lines of investigation in this area.
\end{abstract}

KEY WORDS: planarian, regeneration, neoblast, germ cell, nervous system, eye, signalling molecule

\section{Introduction}

Freshwater planarians (class Turbellaria; Fig. 1) are free-living members of the phylum Platyhelminthes (the flatworms). Molecular phylogeny locates Platyhelminthes together with annelids and molluscs in the Lophotrochozoan clade (Carranza et al., 1997). They are triploblastic, acoelomate, unsegmented, and dorsoventrally flattened soft-bodied organisms, without circulatory, respiratory, or skeletal structures. A pharynx and a blind gut lacking an anus form the digestive system. A solid mass of tissue, called mesenchyme or parenchyma, fills the space between the epidermis and the gut (for a recent review, see Saló, 2006). The most peculiar cell type in planarians is a small, round or ovoid undifferentiated cell called the neoblast (Fig. 2A). These cells are the only mitotically active cells in planarians (Baguñà, 1981, Baguñà and Romero, 1981) and they differentiate to form all planarian cell types, including the germ line (reviewed in Saló, 2006; Handberg-
Thorsager et al., 2008). Such unique cell behaviour endows planarians with a remarkable morphological plasticity through which the animal can regenerate from almost any body piece and change its adult size according to availability of food. When a planarian is cut, the wound epithelium contracts and a thin film of old epidermis covers it in less than an hour (Fig. 2B) (Baguñà et al., 1988). Below the wound epithelium, groups of undifferentiated cells produced by proliferation in the underlying old parenchyma aggregate to produce a new undifferentiated and non-pigmented new tissue called the blastema, which will grow and differentiate to replace the most distal structures (Fig. 2). The rest of the old tissue readapts to the reduced proportions by cell death, cell proliferation and differentiation. In contrast to other higher organisms, which display a unique developmental process to reach a final adult size, planarians can withstand long periods of starvation without any alteration of their functionality. They shrink from their adult size to their initial size at hatching, and even beyond it.

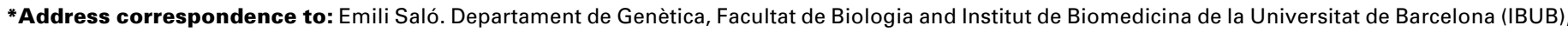
Diagonal 645, 08028 Barcelona, Catalunya, Spain. e-mail: esalo@ub.edu.Web: http://planarian.bio.ub.es/
} 


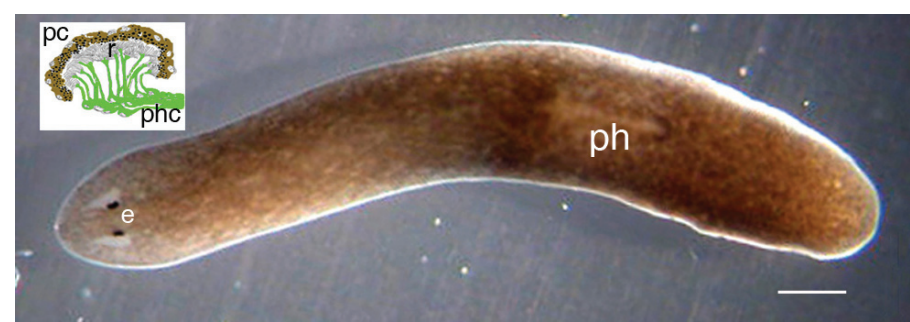

Fig. 1. Dorsal view of the freshwater planarian Schmidtea mediterranea. The animal displays bilateral symmetry and cephalization. The head has two differentiated eye spots (e) with a non-pigmented periglobular area. The insert shows the two basic cell types of the planarian eye spots: the photoreceptor cells (phc) are shown in green with the rhabdomeric structures where the visual pigment accumulates (r) and the pigment cells (pc) in brown. Ph, Pharynx. Scale bar, $1 \mathrm{~mm}$.

More surprisingly, when food is given again, they grow to an adult size without impairment of their physiological capacities. In recent years, a handful of reviews have been published in which these phenomena are further described (Agata and Watanabe, 1999, Baguñà et al., 1994, Newmark and Sánchez-Alvarado, 2002, Reddien and Sánchez-Alvarado, 2004, Saló, 2006, Saló and Baguñà, 2002, Sánchez-Alvarado, 2006, Cebrià, 2007).

Freshwater planarians have asexual, sexual and mixed (sexual/ asexual, usually seasonal) modes of reproduction. Asexual reproduction occurs by transverse fission and produces two new individuals that regenerate the missing parts. Animals from sexually reproducing species are hermaphrodites and reproduce by cross-fertilization; following copulation, they deposit egg capsules from which several hatchlings with the appearance of miniature adults emerge ready to feed and grow. The reproductive system is usually very complex, consisting of multiple testes located dorsally and a pair of ventrally located ovaries with numerous separate vitellaria. The eggs are ectolecithal. The copulatory apparatus is very complex and can be used for taxonomic classification (for a general view of the reproductive system see Saló, 2006).

For more than 20 years, our group has undertaken molecular studies in planarians to characterize a large number of developmental regulatory genes during regeneration, with special emphasis on Hox and homeobox genes, the nervous system, the eye genetic network, germ cell determination and maintenance, and autophagic processes in planarian homeostasis. New strategies such as proteomics are now being applied to characterize factors involved in determination and maintenance of the stem cell lineage, Finally, DNA microarray technology is being used to characterize new genetic components involved in regulation of the CNS and eye morphogenesis, along with more in-depth analysis of elements of the signalling cascade involved in axis determination and maintenance. These lines of research open new avenues towards an understanding of basic biology of planarian regeneration, the results of which can be extrapolated to vertebrates.

This review introduces the main characteristics of planarians as a model system for research into regeneration, summarises the most important research questions being tackled by our group and addresses new and upcoming issues in planarian regeneration.

\section{Early molecular studies of planarian regeneration: the homeobox and Hox genes}

In order to ascertain whether the same developmental gene regulators identified in classical developmental model organisms such as Drosophila and vertebrate models were also involved in controlling planarian regeneration, the basic molecular tools to characterize homeobox and Hox genes in the genome of the planarian Girardia tigrinawere prepared by E. Saló in 1985-1986 during his postdoctoral stay at the Biozentrum (Basel, Switzerland). Using those tools, two homeobox-containing genes, Dth-1 and Dth-2, were identified in Platyhelminthes (García-Fernàndez et al., 1991). They belong to the NK family and display tissuespecific expression: Dth-1 is expressed in cells surrounding the gut while Dth-2 is expressed in peripheral parenchymal cells (García-Fernàndez et al., 1993a). Screening of cDNA and genomic libraries generated from $G$. tigrina using PCR with degenerate oligonucleotides yielded a large number of homeoboxcontaining genes from the paired, POU and, most importantly, the Hox families. From the paired family we characterized two genes: a paired-like gene Dtprd-1(Muñóz-Mármol et al., 1997), which is

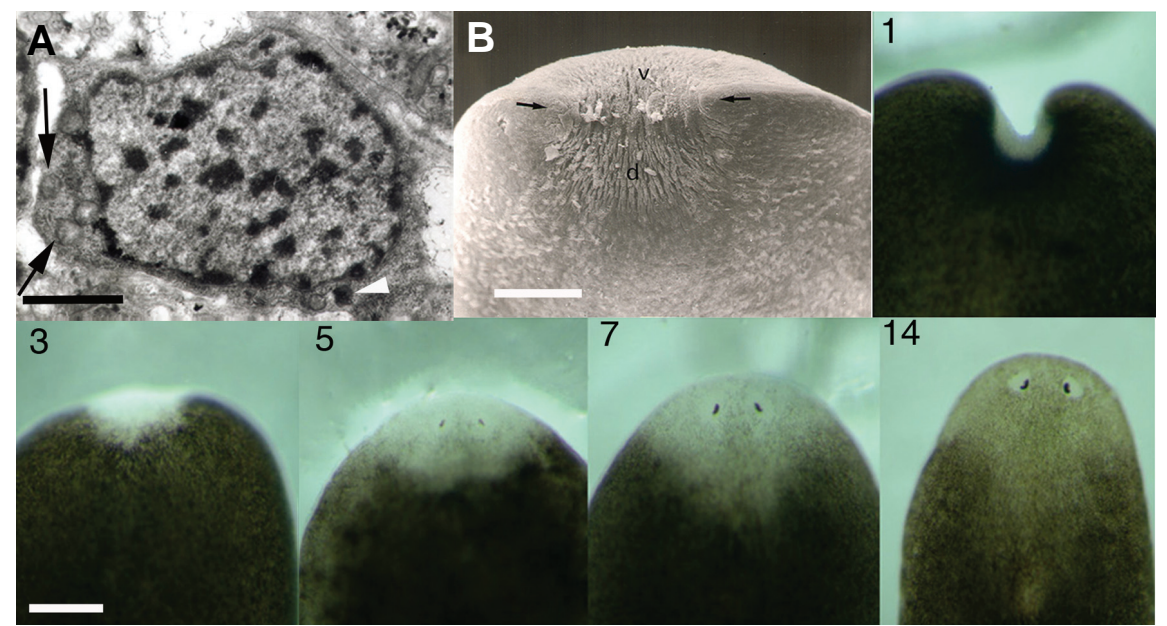

Fig. 2. Planarian head regeneration. (A) Electron microscopy view of an undifferentiated neoblast showing a single nucleus and a small cytoplasmic veil with a few organelles, including free ribosomes, mitochondria (arrows) and chromatoid bodies (white arrowhead). (B) Scanning electron micrograph of the wound area 6 hours after cutting. The wound is completely covered by the old epidermis. The arrows indicate the direction of contraction of the intact sides due to a general muscle contraction. $v$, ventral; $d$, dorsal. Different stages of planarian head regeneration: Numbers refer to days of regeneration. (1) One day later, there is still evidence of muscle contraction in the wound area and the small non-pigmented blastema tissue is visible. In the following panels different stages of head regeneration can be observed with the gradual growth and differentiation of the eyes and pigmented epidermis in the blastema. At 5 days (5) the early differentiation of the eyes and pigmentation of the epidermis is visible. At 14 days (14), the planarian reaches new appropriate proportions according to the reduced size. Scale bars: $A, 3 \mu \mathrm{m} ; B, 0.2 \mathrm{~mm} ; 1-14,1 \mathrm{~mm}$. 
expressed in cyanophilic ventral gland cells, and a Pax-6 family gene (Callaerts et al., 1999), which later allowed research to be undertaken into the gene network controlling planarian eye determination. We also studied three POU domain genes. One of them, GtPOU-1, was found to be ubiquitously expressed, but a specific C6 epitope raised against the GtPOU-1 fusion protein labelled neural cells from the anterior third of adult planarians. This epitope is dynamically expressed during regeneration and pro- vided the first molecular evidence of morphallactic processes during planarian regeneration (Muñóz-Mármol et al., 1998). Planarians contain a large number of Hox genes that can be accommodated into the canonical series of paralogous groups from Plhox-1 to Plhox-9(Saló et al., 2001). However, only P/hox-5, -6 and -9 display differential axial nested expression-the rest are ubiquitously expressed. These genes are activated during the first day of tail regeneration and down-regulated during head

TABLE 1

\section{SUMMARY OF GENES CHARACTERIZED IN FRESHWATER PLANARIANS (ORDER TRICLADIDA)}

\begin{tabular}{|c|c|c|c|c|}
\hline Marker & Species & Gene & $\begin{array}{l}\text { Expression and/or } \\
\text { functional Features }\end{array}$ & Reference \\
\hline \multicolumn{5}{|l|}{ Axial Genes } \\
\hline \multirow[t]{2}{*}{ Hox genes } & Gt & Gthox & Ubiquitous \& AP axis & $\begin{array}{l}\text { (Saló et al., 1995, Saló et al., 2001) (Bayascas et al., 1998a, } \\
\text { Bayascas et al., 1997, Bayascas et al., 1998b) }\end{array}$ \\
\hline & $S m$ & SmedHox & Ubiquitous \& AP axis & Work in progress \\
\hline \multicolumn{5}{|l|}{ Cephalic Genes } \\
\hline Orthodenticle & Gt & DtOtx & Cephalic ganglia & (Stornaiuolo et al., 1998) \\
\hline Six-3 & Gt & Gtsix-3 & Brain branches & (Pineda and Saló, 2002) \\
\hline \multicolumn{5}{|l|}{ Patterning Genes } \\
\hline $\begin{array}{l}\text { Bone } \\
\text { morphogenetic } \\
\text { proteins (BMPs) }\end{array}$ & $S m$ & $\begin{array}{l}\text { Smed/BMP } \\
\text { Smed-Smad1 } \\
\text { Smed-nlg-1 } \\
\text { Smed-noggin1 }\end{array}$ & $\begin{array}{l}\text { Dorsal midline } \\
\text { Mesenchyme, pharynx, CNS } \\
\text { Cephalic branches } \\
\text { CNS, dorsal midline }\end{array}$ & (Molina et al., 2007) \\
\hline \multirow{2}{*}{$\begin{array}{l}\text { Wnt-pathway } \\
\text { proteins }\end{array}$} & Gt & Gtwnt-5 & External and iterative CNS cells & (Marsal et al., 2003) \\
\hline & $S m$ & $\begin{array}{l}\text { SmedB-cat's } \\
\text { SmedGsk-3 }\end{array}$ & Ubiquitous expression, Neural regeneration & $\begin{array}{l}\text { (Iglesias et al., 2008) } \\
\text { (Adell et al., 2008) }\end{array}$ \\
\hline \multicolumn{5}{|l|}{ Germ Cell Markers } \\
\hline Nanos-related gene & $S m$ & Smednos & Precursor germ cell determination and maintenance & (Handberg-Thorsager and Saló, 2007) \\
\hline \multicolumn{5}{|l|}{ Neural Markers } \\
\hline POU-domain protein & Gt & GtPOU-1 & Anterior nerve cells & (Muñóz-Mármol et al., 1998) \\
\hline \multicolumn{5}{|l|}{ Eye Markers } \\
\hline Pax-6 & Gt & $\begin{array}{l}\text { GtPax-6A } \\
\text { GtPax-6B }\end{array}$ & Eye cells & $\begin{array}{l}\text { (Callaerts et al., 1999) } \\
\text { (González-Estévez et al., 2003, Pineda et al., 2001, Pineda et } \\
\text { al., 2002, Saló et al., 2002) }\end{array}$ \\
\hline Sine oculis & Gt & Gtso & Eye cell determination and maintenance & (Pineda et al., 2000, Pineda et al., 2001, Saló et al., 2002) \\
\hline Eyes absent & $D j$ & Djeya & Eye cell determination and maintenance & (Mannini et al., 2004) \\
\hline Opsin & Gt & Gtops & Photoreceptors & (Pineda et al., 2000) \\
\hline \multicolumn{5}{|l|}{ Cell-Specific Markers } \\
\hline Paired-like gene & Gt & Dtprd-1 & Secretory gland cells & (Muñóz-Mármol et al., 1997) \\
\hline $\begin{array}{l}\text { NK-type } \\
\text { homeobox genes }\end{array}$ & Gt & $\begin{array}{l}\text { Dth-1 } \\
\text { Dth-2 }\end{array}$ & $\begin{array}{l}\text { Gastrodermal cells } \\
\text { Parenchyma cells }\end{array}$ & (García-Fernàndez et al., 1991, García-Fernàndez et al., 1993a) \\
\hline Myosin heavy chain & Gt & Gtmhc & Muscle cells & (Cebrià et al., 1999, Cebrià et al., 1997) \\
\hline \multicolumn{5}{|l|}{ Regional Markers } \\
\hline $\begin{array}{l}\text { C-type multidomain } \\
\text { free lectins }\end{array}$ & Gt & $\begin{array}{l}\text { Scarf1, 2, } 3 \\
\text { Gtlec1, 2a, 2b, 2c }\end{array}$ & Parenchyma pre-pharyngeal region & (Shagin et al., 2002) \\
\hline \multicolumn{5}{|l|}{ General Markers } \\
\hline $\begin{array}{l}\text { Protein tyrosine } \\
\text { kinases }\end{array}$ & Gt & Spk-1 & Continuous expression during regeneration & (Burgaya et al., 1994) \\
\hline $\begin{array}{l}\text { Planarian Mariner } \\
\text { Transposon }\end{array}$ & Gt & Pmar-1 & All cells & (García-Fernàndez et al., 1995, García-Fernàndez et al., 1993b) \\
\hline $\begin{array}{l}\text { Dead Associated } \\
\text { Protein }\end{array}$ & Gt & GtDap-1 & Cells in autophagy, induces cell death & $\begin{array}{l}\text { (González-Estévez et al., 2007a, González-Estévez et al., } \\
\text { 2007b, Tettamanti et al., 2008) }\end{array}$ \\
\hline \multicolumn{5}{|l|}{ miRNAs } \\
\hline let-7 & Gt & Let-7 & Not determined & (Pasquinelli et al., 2003) \\
\hline
\end{tabular}

Species abbreviations: Dj, Dugesia japonica; Gt, Girardia tigrina, Sm, Schmidtea mediterranea. 
regeneration (Bayascas et al., 1998a, Nogi and Watanabe, 2001, Orii et al., 1999, Saló and Baguñà, 2002). For a summary of the genes characterized by our group see Table1.

\section{Main topics currently under study in planarian regen- eration and homeostasis}

Several strategies have been developed in the last decade to analyze the function of the isolated genes in planarian regeneration. The first was RNA-mediated genetic interference (RNAi) by application of dsRNA to silence endogenous transcripts with an identical sequence and thereby generate loss-of-function phenotypes. This strategy was originally developed in Caenorhabditis elegans (Fire et al., 1998) and then successfully adapted for use in planarians (Sánchez-Alvarado and Newmark, 1999). We used RNAi to produce the first non-eye phenotype by interfering with expression of sine oculis, one of the genes of the conserved genetic network involved in early eye determination (Pineda et al., 2000). The second strategy involves the production of gain-offunction phenotypes by transgenesis. To that end we developed a new strategy by injection of DNA constructs flanked with repeated transposable sequences plus a second vector that contains a specific helper to facilitate integration. To facilitate transfer to the nucleus the animals injected with the constructs were immediately electroporated with a single pulse of 60 volts/ $\mathrm{cm}^{2}$ for 30 milliseconds with electrodes used in zebrafish embryos. This produced a mosaic in which some neoblasts displayed transformation. Transformed sexual mosaic strains produced transgenic planarians in the next generation through germ cells derived from transformed neoblasts (González-Estévez et al., 2003).

To improve the characterization of the phenotypes generated using these strategies, a large number of new molecular markers have been developed based on the characterization of gene expression patterns by in situ hybridization and immunohistochemistry. The initial list of genes characterized by similarity using cDNA libraries and PCR amplification using degenerate oligonucleotides (see Table 1) was completely overtaken with the production of large collections of expressed sequenced tags (ESTs) (Mineta et al., 2003, Sánchez-Alvarado et al., 2002, Zayas et al., 2005). There has been an effort to sequence the genome of a clonal line of Schmidtea mediterranea sexual strain at the Genome Sequencing Center at Washington University, St. Louis (WUSL, http://genome.wustl.edu/genome.cgi?GENOME= Schmidtea\%20mediterranea), following its prioritization in March 2003 by the National Human Genome Research Institute (NHGRI, you can find details of the original whitepaper proposal at http:// www.genome.gov/12512286). By 2006 a high coverage assembly, 11.60X Q20, was already available from WUSL, and had an estimated length of $865 \mathrm{Mbp}$. It was composed of a set of nearly 90,000 contigs instead of 8 chromosome sequences, mainly due to intrinsic characteristics of the genome in this species. According to WUSL, the low $\mathrm{G}+\mathrm{C}$ content $(31 \%)$, large amount of repetitive sequences ( $46 \%$ of the total genome), sequence heterozygosity (even though the animals used for DNA preparation were clonally derived), and further problems with BAC library preparations, makes this assembly hard to finish. High rates of polymorphism have presented challenges for the assembly in other invertebrate species, such as sea urchin (Sodergren et al.,
2006) or Ciona savigny (Vinson et al., 2005). Despite that, all the available genomic sequences, taking into account current genes cloned in planarian relatives, the EST collections (SánchezAlvarado etal., 2002, Zayas etal., 2005), the shotgun sequencing traces and the assembled contig drafts, can prove useful to locate orthologs of genes with known functions in other species or unannotated ones. Those genes may have novel functions in planarians that could play an important role in biological processes such as regeneration. Many examples can be cited for different species, and the use of comparative genomic analysis of Dugesia japonica EST sequences has already proven fruitful in efforts to identify genes expressed in the CNS (Mineta et al., 2003).

Recent in-depth analyses of selected sequences representative of $1 \%$ of the human genome have uncovered a more complex scenario of gene expression and regulation than expected, with many novel functional regions that do not code for proteins (The ENCODE Project Consortium, 2007). The planarian genome cannot be studied in such detail until a better assembly is released. However, we can take advantage of the currently available sequence catalogue to screen for protein coding regions with a custom-designed microarray, using NimbleGen maskless photolitography technologies (Nuwaysir etal., 2002). In addition, a database of open reading frames (ORFs) derived from genomic sequences has been devised in order to extend peptide searches from mass fingerprint spectra in a proteomics analysis. Bioinformatics has an important role to play in the integration of all the data to define annotation hypotheses that will be validated or refuted later at the bench, and also in the analysis of the results obtained with high-throughput technologies used in our current transcriptomics and proteomics approaches.

Such combinations of new methods and innovations should allow us to tackle planarian regeneration from a new perspective. Below we describe the main topics that are being addressed in our laboratory.

\section{Strategies to analyse planarian stem cells or neoblasts}

Planarians have a unique cell type known as neoblasts, which are pluripotent stem cells that proliferate and differentiate into all cell types, including the germ line. Unfortunately the neoblast cell lineages are not established, largely due to the lack of good molecular markers. Since neoblasts may have a stable population of silenced mRNAs, we initiated a proteomic strategy to characterize factors that may be responsible for regulating the totipotent or pluripotent stages of the neoblasts, since that approach would overcome the noise produced by silenced mRNAs. We analysed differential protein expression by 2D fluorescence difference gel electrophoresis (DIGE), comparing control planarians with organisms depleted of neoblasts by either X-rays or piwi silencing by RNAi (Reddien et al., 2005). Protein spots unique to the neoblasts i.e. present in the controls and absent in the irradiated organisms-were analysed by mass spectrometry. The resulting spectral fingerprints were compared with an "in silico" peptide database produced from the complete set of genomic sequences for $\mathcal{S}$. mediterranea. An initial study using this approach led to the identification of heat shock proteins and proteins from the mitotic cytoskeleton, as well as proteins with the conserved PAZ-domain. We expect to characterize new proteins related to specific neoblast functions that will be validated by their 
expression patterns and functional analyses by RNAi (work in progress).

One of the big challenges for the study of neoblasts is to explain how cell homeostasis is maintained in organisms that continuously change their size and can regenerate a complete, normally proportioned animal in two weeks. The isolation and functional characterization of a dead associated protein-like gene in planarians, Gtdap-1, has allowed us to analyse the importance of cell autophagy and cell death in that process (González-Estevez et al., 2007a; González-Estevez et al., 2007b; Tettamanti et al., 2008). Autophagy refers to a process of cell recycling through lysosomal degradation, allowing recycling of material for macromolecular synthesis and/or ATP generation. We observed a rapid upregulation of Gtdap-1 when the planarian is undergoing architectural remodelling or when cells need to generate intracellular nutrients and energy during starvation. Inhibition of Gtdap-1 by RNAi revealed remodelling defects and a decrease in the speed of regeneration that we attribute to a reduction in autophagy and autophagic programmed cell death. Overexpression of Gtdap-1 by transgenesis in planarians under conditions of stress induces programmed cell death (González-Estevez et al., 2007a). Those findings confirm the role of autophagy as an essential mechanism to maintain the proportionality of the different cell types in planarians and provide the energy required for neoblast proliferation and differentiation in such situations.

\section{The planarian germline}

$S$. mediterranea exists as two strains, a sexually reproducing and an asexually reproducing strain. Whereas the hermaphroditic sexual strain reproduces by cross-fertilization, the asexual strain reproduces uniquely by fission and does not possess reproductive organs. However, it has been described that under certain conditions (temperature below $12^{\circ} \mathrm{C}$ and intensive feeding, twice per week) the asexual strain can develop gonads and copulatory apparatus, but without producing fertile cocoons (Benazzi et al., 1975).

How the germline is determined in planarians is still an open question, but based on earlier studies carried out by Thomas H. Morgan (Morgan, 1902) it has been suggested that an epigenetic mechanism is involved in segregation of the germline from the totipotent neoblasts (Zayas et al., 2005). Morgan showed that if you amputate the planarian at a level anterior to the gonads both the piece that contains germ cells and the piece that does not can regenerate an entire planarian with a fertile reproductive system. At the same time, W. Curtis (Curtis, 1902) described the formation of the reproductive organs in juveniles, which do not posses these organs on hatching, and during sexualization of asexual planarians of the species Planaria maculata. With the recent characterization of a planarian nanosgene in the planarian species $\mathcal{S}$. mediterranea (Smednosor Smed-nanos) and Dugesia japonica (Djnos), it is now possible to distinguish gonad primordia in juvenile and immature adult sexual planarians as well as in asexual planarians (Handberg-Thorsager and Saló, 2007, Sato et al., 2006, Wang et al., 2007). The zinc-finger proteins from the nanos family of translational regulators have been shown to play an essential role in germline development and maintenance in a wide variety of organisms using different modes (epigenesis or preformation) to determine the germline (reviewed in Parisi and Lin, 2000).

In $S$. mediterranea, nanos expression is observed already at late stages of embryogenesis (Fig. 3A; stage 8 according to Cardona et al., 2005) in the presumptive male germ cells, suggesting that the germline is segregated during or at least by late stages of embryogenesis (Handberg-Thorsager and Saló, 2007). In juvenile planarians and during sexualization of $\mathcal{S}$. mediterranea and $D$. japonica, nanosis expressed in the presumptive primordial germ cells of both the testes and the ovaries. The expression of nanos corresponds to clusters of cells with no clear or known morphological structure, but as the planarian matures sexually and the gonads develop, nanos expression is restricted to the periphery of the gonads, corresponding to the spermatogonia in the testes and to the oogonia in the ovaries (Fig. 3B) (HandbergThorsager and Saló, 2007, Sato et al., 2006, Wang et al., 2007). A knock-down of nanos in sexually reproducing $\mathcal{S}$. mediterranea resulted in a loss of the development, formation and maintenance of the germ cells in juveniles, regenerating and intact planarians, respectively (Wang et al., 2007).

Remarkably, expression of nanos was also found in presumptive primordial male and female germ cells in asexually reproducing planarians (Fig. 3C). The expression in dorsally and ventrally located clusters of cells shows high similarity to that found in the juvenile and immature sexual planarian (Handberg-Thorsager and Saló, 2007, Sato et al., 2006, Wang et al., 2007). These observations suggest that even though the asexual strain does not reproduce sexually, it does possess clusters of primordial germ cells. Interestingly a knock-down of nanos in the asexual strain of $S$. mediterranea resulted in a loss of the clusters of primordial germ cells, as demonstrated with germinal histone H4, which labels presumptive germ cells and neoblasts (Wang et al., 2007).

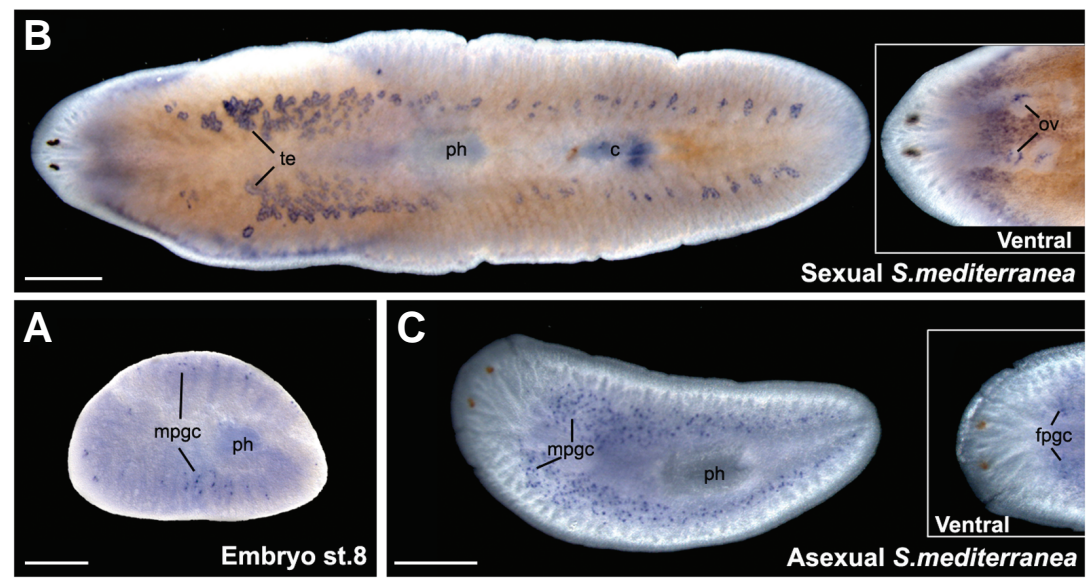

Fig. 3. Whole-mount in situ hybridization of nanos in Schmidtea mediterranea. (A) Expression of nanos in male primordial germ cells during late development of an embryo (stage 8). (B) In the sexually mature S. mediterranea, nanos is expressed in the spermatogonia of the testes located on the dorsal side of the animal and in the oogonia of the ovaries, which are located in an anterior-ventral position (insert). (C) In asexual S. mediterranea gonad primordia can be detected with nanos on the dorsal side in male primordial germ cells and on the ventral side in female primordial germ cells (insert). Anterior is to the left. Dorsal view. Ventral view of the same planarian shown in the insert. c, copulatory apparatus; fpgc, female primordial germ cells; mpgc, male primordial germ cells; ph, pharynx; ov, ovaries; te, testes. Scale bar, $1 \mathrm{~mm}$. 
Further characterization of nanos-positive cells demonstrated that these indeed have characteristics of undifferentiated cells. In situ hybridization analyzed by electron microscopy showed that nanos transcripts are located in the chromatoid body and nanospositive cells are labeled with PCNA, which is essential for DNA replication and is found in proliferating cells (Sato et al., 2006). Furthermore nanos expressing cells are sensitive to irradiation (Handberg-Thorsager and Saló, 2007, Sato et al., 2006, Wang et al., 2007), suggesting that these cells are either dependent on the neoblasts, which are eliminated upon irradiation, or that they stop expressing nanosand change their cell fate. Finally, Sato et al. (2006) showed by BrdU incorporation that nanos-positive cells in sexual planarians are proliferative cells and incorporate BrdU,
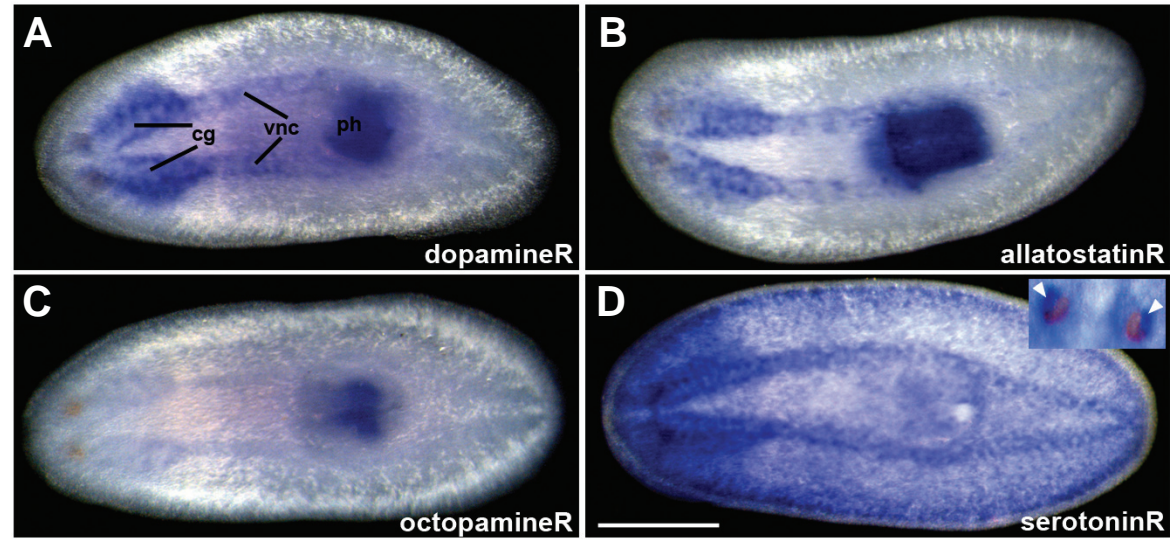

Fig. 4. Whole-mount in situ hybridization for homologs of receptors for neuroactive substances in Schmidtea mediterranea. Arrows indicate serotonin receptor expression in the photosensitive cells in the inset in (D). Anterior to the left. cg, cephalic ganglia; vnc, ventral nerve cords. Scale bar, $1 \mathrm{~mm}$ whereas nanos-positive cells in asexual animals seem to be potential proliferative cells since they are labeled with PCNA but they do not incorporate BrdU. Those authors proposed that nanos-positive cells in asexual planarians could be in cell cycle arrest.

A number of germ-cell markers in mature gonads have been described in planarians, including $D e Y 1$, a component of ribonucleoprotein particles (Salvetti et al., 2002), DjPTK-1, a receptor protein tyrosine kinase (Ogawa et al., 1998), PCNA, a proliferating cell protein (Orii et al., 2005), vasa, a germ granule-specific gene (Shibata et al., 1999) and a variety of genes from the EST collection from sexual $\mathcal{S}$. mediterranea (Zayas et al., 2005). However, with the recent description of nanos (HandbergThorsager and Saló, 2007, Sato et al., 2006, Wang et al., 2007) and germinal histone H4 (Wang et al., 2007), it is now possible to detect and describe gonad primordia at an early stage of development of the reproductive system.

\section{Determination and maintenance of axial polarity: Wnt and BMP signalling pathways}

How polarity is re-established along the anteroposterior (AP) and dorsoventral (DV) axes during planarian regeneration is still largely unknown. Many studies have shown that the Wnt and BMP signalling pathways function in highly conserved mechanisms responsible for correct patterning and morphogenesis during development and that they are required for AP and DV patterning, respectively, in both vertebrates and invertebrates (reviewed in De Robertis and Kuroda, 2004, Little and Mullins, 2006, Niehrs, 2004). Unravelling the function of these signalling pathways in planarians will clarify whether they are responsible for axis reestablishment during regeneration. Moreover, these studies will give us clues as to whether the mechanisms responsible for patterning during development are also used in regeneration.

Wnt signalling regulates a broad range of cell processes, such as stem cell maintenance, cell fate specification, determination of cell polarity and cell migration (reviewed in Logan and Nusse, 2004, Reya and Clevers, 2005). During early development, the Wnt pathway is involved in axis specification and germ layer establishment from mammals to cnidarians (reviewed in Croce and McClay, 2006, Lee et al., 2006, Marikawa, 2006). At later developmental stages it is responsible for conferring head versus tail identity (reviewed in Holland, 2002, Niehrs, 1999). The Wnt pathway is not only activated during development but also in adult organisms, where it is involved in tissue self-renewal and tumorigenesis (reviewed in Clevers, 2006). Through its role in stem cell maintenance, the Wnt pathway has been demonstrated to be required for regeneration in fish and amphibian appendages (Caubit et al., 1997, Stoick-Cooper et al., 2007) and mammalian tissues (Osakada et al., 2007). Despite the requirement for Wnt activation in regeneration, a role for elements of the Wnt pathway in re-patterning the regenerating tissue has only been demonstrated in cnidarians. Experiments in hydra and Nematostella demonstrate that Wnt signalling is involved in axis formation, patterning and germ-layer specification not only during embryogenesis but also during regeneration (rev in Lee et al., 2006).

In vertebrates, the BMP pathway specifies ventral cell fates during embryogenesis. Mutations in BMP genes result in a dorsalizing phenotype, whereas mutations in antagonists of this pathway, such as noggin or chordin, give rise to a ventralized phenotype (reviewed in De Robertis and Kuroda, 2004). On the contrary, BMP specifies dorsal cell fates in invertebrates.

Research in our laboratory has sought to address whether the Wnt and BMP pathways are required during planarian regeneration for both blastema growth and body patterning. Interestingly, two recent reports suggest that during planarian regeneration both pathways are required for patterning. Kobayashi etal. (2007) demonstrated the involvement of the Wnt pathway in AP patterning of the CNS in the planarian species $D$. japonica, while Orii and Watanabe (2007) reported a role for a BMP gene in DV patterning. Previously, our group reported the isolation of a member of the Wnt family, Gt-wnt5, which is expressed in the CNS (Marsal et al., 2003). From the available genomic database of $S$. mediterranea we have identified several elements of the Wnt pathway that are currently being characterized (Wnts, TCFs, frizzleds, dishevelled, GSK3, axin, beta-catenin). Inhibition of GSK3 using synthetic drugs has been successfully used in cnidarians to demonstrate the role of the Wnt pathway in pattern formation during regeneration (reviewed in Lee et al., 2006). Using the same strategy we have demonstrated that GSK3 is required for normal regeneration of the nervous system in $\mathcal{S}$. mediterranea (Adell et al., 2008). 
GSKs inhibited animals showed a delayed and improper regeneration of the anterior structures, while the posterior regenerated normally, suggesting that also in planarians the Wnt pathway could have a role in AP axis patterning. Recently, the requirement of the canonical wnt pathway for AP axis establishment and maintenance during planarians regeneration and normal homeostasis has been certainly demonstrated (Gurken et al., 2008; Pettersen and Reddien 2008, Iglesias et al., 2008). Inhibition of Smed- $\beta$ catenin1 leads to a striking phenotype: radial-like hypercephalized animals, in which the AP axis polarity is abolished, while the DV remains unaffected (Iglesias et al., 2008). Moreover, inhibition of APC, a component of the $\beta$-catenin destruction complex, leads to the opposite phenotype, planarians which are not able to regenerate the head, showing a tail structure instead (Gurken et al., 2008). Similarly, several members of the BMP pathway, including homologues of BMP, Smad and noggin, have also been isolated from $S$. mediterranea (Molina etal., 2007, Reddien et al., 2007). RNAi-based silencing of Smed-BMP or Smed-Smad1 results in a major disruption of the DV axis in both intact and regenerating animals. Mainly, the dorsal side of the treated planarians looses the expression of dorsal specific markers at the same time that ventral specific markers are ectopically expressed. In addition to this partial ventralization of the dorsal side, a duplicated CNS differentiates dorsally on those RNAitreated animals (Molina et al., 2007). Also, the BMP pathway has been proposed to regulate dorsal midline and asymmetric regeneration (Reddien et al., 2007). These results indicate that the BMP pathway is essential for the re-specification and maintenance of the DV axis in planarians.

\section{The influence of the nervous system on planarian regenera- tion}

Over the years, a variety of experimental evidence has suggested a role for the nervous system in planarian regeneration. Evidence supporting a pivotal role for the nervous system in regulating key events during regeneration, such as cell proliferation and differentiation, has been obtained from both classical experiments-mainly carried out through amputation at different levels along the AP axis, removal of the ventral nerve cords from the regenerating pieces or grafting tissue fragments into different body regions (reviewed in Brondsted, 1969)—and the more recent molecular-based approaches. However, the exact nature of this putative neural influence remains mostly uncharacterized. In the early 1950s Wolff and Lender carried out several experiments that indicated a requirement for brain regeneration prior to eye differentiation, suggesting an inductive role for the brain (Lender, 1952, Wolff and Lender, 1950). More recently, nou darake, an FGF receptor-like gene specifically expressed in the planarian cephalic region, has been shown to restrict the differentiation of brain tissues in this region (Cebrià et al., 2002). Also, abnormal regeneration of the central nervous system after Smed roboARNAi has been correlated with the differentiation of ectopic pharynges and dorsal outgrowths with head identity (Cebrià and Newmark, 2007). In the absence of proper connections between the newly differentiated brain and ventral nerve cords, putative neurally derived signals could be present in the surrounding tissues, altering the behaviour of the neoblasts and inducing the morphogenesis defects observed (Cebrià and Newmark, 2007).

Neurotransmitters and growth factors have been also implicated in regulating stem cell fate in different systems. In planarians, the presence of neurons expressing serotonin, FMRFamide, EGF receptor, met-enkephalin (opioid neuropeptide) and neuropeptide $F$ has been reported based on immunocytochemistry (Reuter and Gustafsson, 1995, Venturini et al., 1983). Furthermore, indirect evidence mostly obtained through the use of agonists or antagonists of some of these neural factors suggest putative roles during planarian regeneration. For example, serotonin, one of the most ubiquitous neurotransmitters in animals, and dopamine increase rates of regeneration (Franquinet, 1979, Franquinet and Le Moigne, 1979), and substance $P$ and substance $\mathrm{K}$ seem to have a stimulatory effect on neoblast proliferation (Baguñà et al., 1989, Saló and Baguñà, 1986). In contrast, somatostatin has been suggested to have an inhibitory effect on proliferation (Bautz and Schilt, 1986). However, despite the role these factors might play in regeneration, the genes are not well characterized. Thus, except for four serotonin receptor-like genes (Saitoh et al., 1997), several ESTs from Dugesia japonica showing homology to different neurotransmitters (Mineta et al., 2003), and recent characterization of genes expressed in dopaminergic and serotonergic neurons (Nishimura et al., 2007a, Nishimura et al., 2007b), little is known about these neurotransmitters and their receptors in planarians. In our laboratory we are taking advantage of the available data on the $\mathcal{S}$. mediterranea genome in order to isolate those genes and characterize their function during regeneration. Using the amino acid sequences of several neurotransmitter receptors from different vertebrates and invertebrates, tblastn searches were carried out against $\mathcal{S}$. mediterranea genomic sequences. Following this in silico approach, several genomic contigs containing putative ORFs coding for several
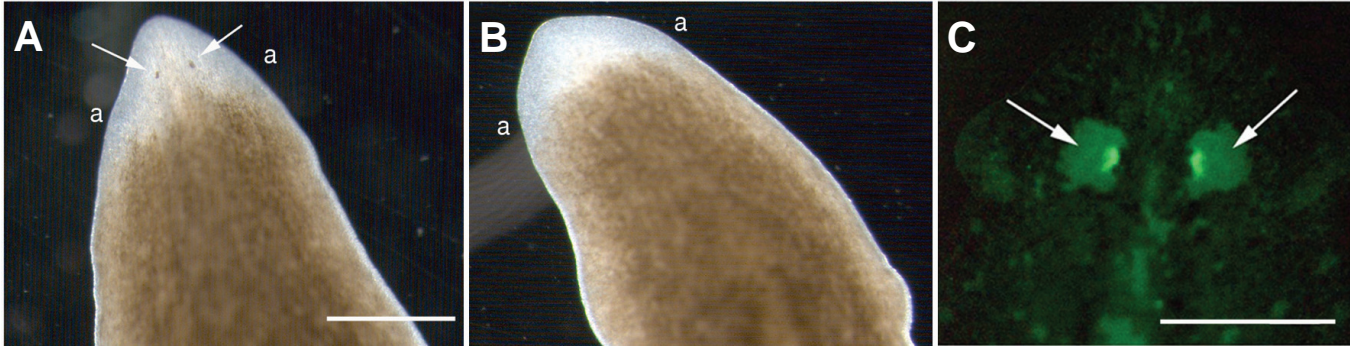

Fig. 5. New genetic methods applied to studies of planarian regeneration. (A,B) Inhibition of eye regenerative capacity by Smedsix-1 dsRNA (work in progress). Bright-field images of dorsal views of living regenerated planarian heads in Schmidtea mediterranea. (A) Control showing a regenerated head with differentiated eyes (arrows). (B) dsRNA-fed animal; although the head is normal with a complete brain (not shown) and auricle, no eyes or periglobular area (non-pigmented epidermis in the top of the eye) are observed. a, auricles. (C) Fluorescence view of a transgenic planarian head in Girardia tigrina transformed by electroporation with EGFP Hermes-derived vector constructs (González-Estévez et al., 2003). A homogeneous fluorescent signal is observed in the photoreceptor cells of both eyes. Scale bar, $1 \mathrm{~mm}$. 
types of receptors have been isolated. These include candidate genes for the planarian homologs of receptors for serotonin, dopamine, octopamine, allatostatin, FMRFamide, somatostatin and neuropeptide F. Specific primers have been designed and used to amplify some of these genes from $\mathcal{S}$. mediterraneacDNA. Whole mount in situ hybridizations for dopamine, allatostatin, octopamine and serotonin receptors show that all of them are expressed, at different levels, in the CNS (Fig. 4). In addition dopamine, allatostatin and octopamine receptors are also expressed in the pharynx, probably in its neural plexus. The serotonin receptor is also expressed in the photosensitive cells (panel in Fig. 4D). Further analysis will allow us to characterize the function of these genes during planarian regeneration.

\section{The eye genetic network}

Planarian eyes are well-defined sensory structures, generally located on the dorsal side of the third branch of cephalic ganglia and grouped together into simple eyespots or ocelli (Sakai et al., 2000). They are composed of two characteristic cell types, photoreceptors and pigmented cells (Fig.1). Photoreceptors are bipolar neurons. Their axons project caudally to the dorsomedial side of the cephalic ganglia, with some axons from each side projecting contralaterally across the midline to produce an optic chiasm, which integrates photosensory inputs from both sides (Sakai et al., 2000). Dendritic extremities generally have a rhabdomeric structure, a regularly ordered microvilli assembly, where opsin accumulates (Orii et al., 1998). The pigmented cells group to form an eyecup which surrounds the rhabdomeres (Fig. 1). Since the initial characterization of the Pax6 gene, we have continued the search for planarian orthologs of genes involved in eye determination (Table 1). We confirmed that the initial eye genetic network is highly conserved in planarians compared to other metazoans, with the characterization of orthologs of sine oculis, eyes absentand opsingenes in different planarian species (Mannini et al., 2004, Pineda et al., 2002, Saló et al., 2002). Loss of function of sine oculis and eyes absentconfirms their function in eye determination during regeneration and maintenance in adult planarians (Fig. 5A, B) (Mannini et al., 2004, Pineda et al., 2000). Also, the production of transgenic planarians carrying several dimeric Pax6 binding sites plus an enhanced green fluorescent protein reporter gene produces a new phenotype in which the planarians show green eyes (Fig. 5C) (GonzálezEstévez et al., 2003). The complex expression pattern of components of the eye genetic network can now be studied in $\mathcal{S}$. mediterraneaby DNA microarray technology in different non-eye phenotypes. This may provide a list of candidate downstream genes and suggest the type of interactions with the conserved early eye genetic network (work in progress).

\section{Conclusions}

Due to their extreme morphological plasticity, planarians have provided many scientists with an attractive model organism for centuries. Their high regenerative capacity along with the presence of a totipotent stem cell system that is unique in the metazoans provides an ideal model system for studying regeneration, pattern formation and stem cell regulation. In addition, the availability of new genomic and proteomic techniques should permit the characterization of novel genes as well as those loci with as yet unknown functions. Other advances, including the ability to create knock-down phenotypes by RNAi, perform transgenesis and characterize miRNAs, as well as the possibility of analyzing cell lineages, should enable longstanding questions to be answered. Since the planarian genome represents one of the first complete genomes available from within the lophotrochozoa, comparative genomics with ecdysozoa and deuterostomes will become an important tool for identifying candidate genes and regulatory elements involved in the complex biology of metazoans.

\section{Acknowledgements}

The authors wish to thank all those colleagues, postdoctoral researchers and postgraduate students working on their theses in the Departament de Genetica (Universitat de Barcelona) who, over the last twenty years, have contributed to the results mentioned in this review. We thank Prof. W. Gehring's group and Dr. Cristina Gonzallez-Estevez for help and advice on the eye genetic network and transgenesis; Dr R. Batistoni's group for the long and intense collaboration on the eye genetic network; DrM. Pala for providing the sexual strain ofS. mediterranea and Dr. lain Patten for critical comments and corrections. This work was supported by grants BMC2002-03992 and BFU2005-00422 from the Ministerio de Educación y Ciencia, Spain, and grant 2005SGR00769 from AGAUR (Generalitat de Catalunya). TA received a $C$ - $R E D$ postdoctoral fellowship from Generalitat de Catalunya and $F C$ is the recipient of a Ramón y Cajal fellowship from the Ministerio de Educación y Ciencia, Spain. KF-T and $G R-E$ are recipients of FPI fellowships, and MH-T and MDM are supported by FPU fellowships from the Ministerio de Educación y Ciencia, Spain. Finally KE and MI are the recipients of fellowships from the Generalitat de Catalunya and University of Barcelona, respectively.

\section{References}

AGATA, K. and WATANABE, K. (1999). Molecular and cellular aspects of planarian regeneration. Semin Cel/ Dev Bio/10: 377-83.

ADELL, T., MARSAL, M. and SALÓ, E. (2008). Planarian GSK3s are involved in neural regeneration. Dev Genes Evol, 218: 89-103.

BAGUÑ̀̀, J. (1981). Planarian neoblasts. Nature 290: 14-15.

BAGUÑÀ, J. and ROMERO, R. (1981). Quantitative analysis of cell types during growth, degrowth and regeneration in the planarians Dugesia mediterraneaand Dugesia tigrina. Hydrobiologia 84: 181-194.

BAGUÑ̀̀, J., SALÓ, E., COLLET, J., AULADELL, C. and RIBAS, M. (1988). Cellular, molecular and genetic approaches to regeneration and pattern formation in planarians. Fortschr. Zool. 36: 65-78.

BAGUÑ̀̀, J., SALÓ, E. and ROMERO, R. (1989). Effects of activators and antagonists of the neuropeptides substance $P$ and substance $K$ on cell proliferation in planarians. Int $J$ Dev Bio/33: 261-6.

BAGUÑÀ, J., SALÓ, E., ROMERO, R., GARCÍA-FERNÀNDEZ, J., BUENO, D., MUÑÓZ-MÁRMOL, A.M., BAYASCAS-RAMÍREZ, J.R. and CASALI, A. (1994) Regeneration and pattern formation in planarians: cells, molecules and genes. Zool. Sci. 11: 781-795.

BAUTZ, A. and SCHILT, J. (1986). Somatostatin-like peptide and regeneration capacities in planarians. Gen Comp Endocrino/64: 267-72.

BAYASCAS, J.R., CASTILLO, E., MUÑÓZ-MÁRMOL, A.M., BAGUNÀ, J. and SALÓ, E. (1998a). Synchronous and early activation of planarian Hox genes and re-specification of body axes during regeneration. Hidrobiologia 383: 125130.

BAYASCAS, J.R., CASTILLO, E., MUÑÓZ-MÁRMOL, A.M. and SALÓ, E. (1997). Planarian Hoxgenes: novel patterns of expression during regeneration. Deve/opment 124: 141-148.

BAYASCAS, J.R., CASTILLO, E. and SALÓ, E. (1998b). Platyhelminthes have a Hoxcode differentially activated during regeneration, with genes closely related to those of spiralian protostomes. Dev. Genes Evol. 208: 467-473. 
BENAZZI, M., BAGUÑ̀̀, J., BALLESTER, R., PUCCINELLI, I. and DEL PAPA, R. (1975). Further contribution to the taxonomy of the Dugesia lugubris-polychroa group with description of Dugesia mediterranea n.sp. (Tricladida, Paludicola). Boll Zoo/42: 81-89.

BRONDSTED, H.V. (1969). Planarian regeneration. Pergamon Press.

BURGAYA, F., GARCÍA-FERNÀNDEZ, J., RIUTORT, M., BAGUÑà, J. and SALÓ, E. (1994). Structure and expression of Spk-1, an src-related gene product formed in the planarian' Dugesia (G) tigrina. Oncogene 9: 1267-1272.

CALLAERTS, P., MUÑÓZ-MÀRMOL, A.M., GLARDON, S., CASTILLO, E., SUN, H., LI, W.H., GEHRING, W.J. and SALÓ, E. (1999). Isolation and expression of a Pax-6gene in the regenerating and intact Planarian Dugesia(G)tigrina. Proc. Natl. Acad. Sci. USA 96: 558-563.

CARDONA, A., HARTENSTEIN, V. and ROMERO, R. (2005). The embryonic development of the triclad Schmidtea polychroa. Development, Genes and Evolution 215: 109-131.

CARRANZA, S., BAGUÑÀ, J. and RIUTORT, M. (1997). Is the Platyhelminthes a Monophyletic Primitive group? An assessment using 18S rDNA sequences. Mol. Biol. Evol. 14: 485-497.

CAUBIT, X., NICOLAS, S. and LE PARCO, Y. (1997). Possible roles for Wntgenes in growth and axial patterning during regeneration of the tail in urodele amphibians. Dev Dyn 210.

CEBRIÀ, F. (2007). Regenerating the central nervous system: how easy for planarians! Dev Genes Evo/217: 733-748.

CEBRIÀ, F., BUENO, D., REIGADA, S. and ROMERO, R. (1999). Intercalary muscle cell renewal in planarian pharynx. Dev Genes Evol209: 249-53.

CEBRIÀ, F., KOBAYASHI, C., UMESONO, Y., NAKAZAWA, M., MINETA, K., IKEO, K., GOJOBORI, T., ITOH, M., TAIRA, M., SÁNCHEZ-ALVARADO, A. et al. (2002). FGFR-related gene nou-darake restricts brain tissues to the head region of planarians. Nature 419: 620-4.

CEBRIÀ, F. and NEWMARK, P.A. (2007). Morphogenesis defects are associated with abnormal nervous system regeneration following roboA RNAi in planarians. Development.

CEBRIÀ, F., VISPO, M., NEWMARK, P.A., BUENO, D. and ROMERO, R. (1997). Myocyte differentiation and body wall muscle regeneration in the planarian Girardia tigrina. Dev Genes Evo/207: 306-316.

CLEVERS, H. (2006). Wnt beta-cateninsignaling in development and disease. Cel/ 127: 469-80.

CROCE, J.C. and MCCLAY, D.R. (2006). The canonical Wntpathway in embryonic axis polarity. Semin Cell Dev Bio/17: 168-74.

CURTIS, W. (1902). The life history, the normal fission, and the reproductive organs of Planaria maculata. Proc. Boston Society of Nat. Hist. 30: 515-549.

DE ROBERTIS, E.M. and KURODA, H. (2004). Dorsal-ventral patterning and neural induction in Xenopus embryos. Annu Rev Cel/ Dev Bio/20: 285-308.

FIRE, A., MONTGOMERY, M., KOSTAS S.A., DRIVER S.E. and MELLO CC. (1998). Potent and specific genetic interference by double stranded RNA in Caenorhabditis elegans. Nature 391:806-811.

FRANQUINET, R. (1979). The role of serotonin and catecholamines in the regeneration of the planaria Polycelis tenvis. J Embryol Exp Morpho/51: 85-95.

FRANQUINET, R. and LE MOIGNE, A. (1979). Relation entre les variations des taux de sérotonine et d'AMP cyclique au cors de la régénération d'une planaire. Biol. Cell. 34: 71-76.

GARCÍA-FERNÀNDEZ, J., BAGUÑÀ, J. and SALÓ, E. (1991). Planarian homeobox genes: Cloning, sequence analysis, and expression. Proc. Natl. Acad. Sci. USA 88: 7338-7342.

GARCÍA-FERNÀNDEZ, J., BAGUÑÀ, J. and SALÓ, E. (1993a). Genomic organization and expression of the planarian homeobox genes Dth-1 and Dth-2. Development 118: 241-253.

GARCÍA-FERNÀNDEZ, J., BAYASCAS-RAMÍREZ, J.R., MARFANY, G., MUÑÓZMÁRMOL, A.M., CASALI, A., BAGUÑÀ, J. and SALÓ, E. (1995). High copy number of highly similar mariner-like transposons in planarian (Platyhelminthe): evidence for a trans-phyla horizontal transfer. Molecular Biology and Evolution 12: 421-431.

GARCÍA-FERNÀNDEZ, J., MARFANY, G., BAGUÑÀ, J. and SALÓ, E. (1993b). Infiltration of mariner elements. Nature 364: 109-10.

GONZÁLEZ-ESTÉVEZ, C., FELIX, A.D., ABOOBAKER, A.A. and SALÓ, E. (2007a).
Gtdap-1 promotes autophagy and is required for planarian remodeling during regeneration and starvation. Proc Nat/ Acad Sci USA USA 104: 13373-13378.

GONZÁLEZ-ESTÉVEZ, C., FELIX, A.D., ABOOBAKER, A.A. and SALÓ, E. (2007b). Gtdap- 1 and the role of autophagy during planarian regeneration and starvation. Autophagy 3; $6: 640-642$.

GONZÁLEZ-ESTÉVEZ, C., MOMOSE, T., GEHRING, W.J. and SALÓ, E. (2003). Planarian transgenic lines obtained by electroporation using transposon-derived vectors and an eye-specific GFP marker. Proc Natl Acad Sci USA 100: 14046-14051.

GURLEY, K.A., RINK, C. and SÁNCHEZ-ALVARADO, S. (2008). B-catenin defines head versus tail identity during planarian regeneration and homeostasis. Science 319: 323-327.

HANDBERG-THORSAGER, M. and SALÓ, E. (2007). The planarian nanos-like gene Smednos is expressed in germline and eye precursor cells during development and regeneration. Development, Genes and Evolution 217: 403411.

HANDBERG-THORSAGER, M., FERNANDEZ, E. and SALÓ, E. (2008). Stem cells and regeneration in planarians. Frontiers in Bioscience 13:6374-6394.

HOLLAND, L.Z. (2002). Heads or tails? Amphioxus and the evolution of anteriorposterior patterning in deuterostomes. Dev Bio/241: 209-28.

IGLESIAS. M., GOMEZ-SKARMETA, J.L., SALÓ, E. and ADELL, T. (2008). Silencing of Smed- $\beta$-catenin1 generates radial-like hypercephalized planarians. Development 135: 1215-1221.

KOBAYASHI, C., SAITO, Y., OGAWA, K. and AGATA, K. (2007). Wntsignaling is required for antero-posterior patterning of the planarian brain Dev Bio/306: 71424.

LEE, P.N., PANG, K., MATUS, D.Q. and MARTINDALE, M.Q. (2006). A WNT of things to come: evolution of Wntsignaling and polarity in cnidarians. Semin Cell Dev Biol. 17: 157-67.

LENDER, T.H. (1952). Le role inducteur du cerveau dans la régénération des yeux d'une planaire d'eau douce. Ann. Biol. 28: 191-198.

LITTLE, S.C. and MULLINS, M.C. (2006). Extracellular modulation of $B M P$ activity in patterning the dorsoventral axis. Birth Defects Res CEmbryo Today 78: 22442.

LOGAN, C.Y. and NUSSE, R. (2004). The Whtsignaling pathway in development and disease. Annu Rev Cell Dev Bio/20: 781-810.

MANNINI, L., ROSSI, L., DERI, P., GREMIGNI, V., SALVETTI, A., SALÓ, E. and BATISTONI, R. (2004). Djeyes absent (Djeya) controls prototypic planarian eye regeneration by cooperating with the transcription factor Djsix-1. Dev Bio/269: 346-59.

MARIKAWA, Y. (2006). Wntt beta-catenin signaling and body plan formation in mouse embryos. Semin Cell Dev Biol 17: 175-84.

MARSAL, M., PINEDA, D. and SALÓ, E. (2003). Gtwnt 5 a member of the wnt family expressed in a subpopulation of the nervous system of the planarian Girardia tigrina. Gene Expr Patterns 3: 489-95.

MINETA, K., NAKAZAWA, M., CEBRIÀ, F., IKEO, K., AGATA, K. and GOJOBORI, T. (2003). Origin and evolutionary process of the CNS elucidated by comparative genomics analysis of planarian ESTs. Proc Natl Acad Sci USA 100: 766671.

MOLINA, M.D., SALÓ, E. and CEBRIÀ, F. (2007). The BMP pathway is essential for re-specification and maintenance of the dorsoventral axis in regenerating and intact planarians. Dev Bio/311: 79-94.

MORGAN, T.H. (1902). Growth and regeneration in Planaria lugubris. Arch Entwicklungsmech Org 13: 179-212.

MUÑÓZ-MÁRMOL, A.M., CASALI, A., CASTILLO, E., BAYASCAS, J.R. and SALÓ, E. (1997). Dtprd-1, a novel planarian paired-like homeoprotein expressed in specific secretory cells. Dev. Genes Evol. 207: 296-305.

MUÑÓZ-MÁRMOL, A.M., CASALI, A., MIRALLES, A., BUENO, D., BAYASCAS J.R., ROMERO, R. and SALÓ, E. (1998). Characterization of Platyhelminth POU domain genes: ubiquitous and specific anterior nerve cell expression of different epitopes of GtPOU-1. Mech. Dev. 76: 127-140.

NEWMARK, P.A. and SÁNCHEZ-ALVARADO, A. (2002). Not your father's planarian: a classic model enters the era of functional genomics. Nat Rev Genet 3 : 210-9.

NIEHRS, C. (1999). Head in the WNT: the molecular nature of Spemann's head 
organizer. Trends Genet 15: 314-9.

NIEHRS, C. (2004). Regionally specific induction by the Spemann-Mangold organizer. Nat Rev Genet 5: 425-34

NISHIMURA, K., KITAMURA, Y., INOUE, T., UMESONO, Y., SANO, S., YOSHIMOTO, K., INDEN, M., TAKATA, K., TANIGUCHI, T., SHIMOHAMA, S. et al. (2007a). Reconstruction of dopaminergic neural network and locomotion function in planarian regenerates. Dev Neurobio/67: 1059-78.

NISHIMURA, K., KITAMURA, Y., INOUE, T., UMESONO, Y., YOSHIMOTO, K., TAKEUCHI, K., TANIGUCHI, T. and AGATA, K. (2007b). Identification and distribution of tryptophan hydroxylase (TPH)-positive neurons in the planarian Dugesia japonica. Neurosci Res.

NOGI, T. and WATANABE, K. (2001). Position-specific and non-colinear expression of the planarian posterior (Abdominal-B-like)gene. Develop. Growth Differ. 43: 177-184.

NUWAYSIR, E.F., HUANG, W., ALBERT, T.J., SINGH, J., NUWAYSIR, K., PITAS, A., RICHMOND, T., GORSKI, T., BERG, J.P., BALLIN, J. et al. (2002). Gene expression analysis using oligonucleotide arrays produced by maskless photolithography. Genome Res 12: 1749-55.

OGAWA, K., WAKAYAMA, A., KUNISADA, T., ORII, H., WATANABE, K. and AGATA, K. (1998). Identification of a receptor tyrosine kinase involved in germ cell differentiation in planarians. Biochem Biophys Res Commun 248: 204-9.

ORII, H., KATAYAMA, T., SAKURAI, T., AGATA, K. and WATANABE, K. (1998). Immunohistochemical detection of opsins in turbellarians. Hydrobiologia 383: 183-187.

ORII, H., KATO, K., UMESONO, Y., SAKURAI, T., AGATA, K. and WATANABE, K. (1999). The planarian HOM HOXHomeobox genes (P/OX) expressed along the anteroposterior axis. Dev. Biol. 210: 456-468.

ORII, H., SAKURAI, T. and WATANABE, K. (2005). Distribution of the stem cells (neoblasts) in the planarian Dugesia japonica. Dev Genes Evo/215: 143-57.

ORII, H. and WATANABE, K. (2007). Bone morphogenetic protein is required for dorso-ventral patterning in the planarian Dugesia japonica. Dev Growth Differ 49: $345-9$

OSAKADA, F., OOTO, S., AKAGI, T., MANDAI, M., AKAIKE, A. and TAKAHASHI, M. (2007). Wntsignaling promotes regeneration in the retina of adult mammals. JNeurosci 27: 4210-9.

PARISI, M. and LIN, H. (2000). Translational repression: A duet of Nanos and Pumilio. Current Biology 10: R81-R83.

PASQUINELLI, A.E., MCCOY, A., JIMÉNEZ, E., SALÓ, E., RUVKUN, G., MARTINDALE, M.Q. and BAGUÑ̇̀, J. (2003). Expression of the 22 nucleotide let-7 heterochronic RNA throughout the Metazoa: a role in life history evolution? Evol. Dev. 5: 372-378.

PETERSEN, C. and REDDIEN, P.W. (2008). Smed-betacatenin-1 is required for anteroposterior blastema polarity in planarian regeneration. Science 319:32730.

PINEDA, D., GONZÁLEZ, J., CALLAERTS, P., IKEO, K., GEHRING, W.J. and SALÓ, E. (2000). Searching for the prototypic eye genetic network: Sine oculis is essential for eye regeneration in planarians. Proc. Natl. Acad. Sci. USA 97: 4525-4529

PINEDA, D., GONZÁLEZ, J., MARSAL, M. and SALÓ, E. (2001). Evolutionary conservation of the initial eye genetic pathway in planarians. Belg. J. Zool. 131: 77-82.

PINEDA, D., ROSSI, L., BATISTONI, R., SALVETTI, A., MARSAL, M., GREMIGNI, V., FALLENI, A., GONZÁLEZ-LINARES, J., DERI, P. and SALÓ, E. (2002). The genetic network of prototypic planarian eye regeneration is Pax-6 independent. Development 129: 1423-1434.

PINEDA, D. and SALÓ, E. (2002). Planarian Gtsix3, a member of the Six/sogene family, is expressed in brain branches but not in eye cells. Mech Dev119 Suppl 1: S167-71.

REDDIEN, P.W., BERMANGE, A.L., KICZA, A.M. and SÁNCHEZ ALVARADO, A. (2007). BMP signaling regulates the dorsal planarian midline and is needed for asymmetric regeneration. Development. 4043-51.

REDDIEN, P.W., OVIEDO, N.J., JENNINGS, J.R., JENKIN, J.C. and SÁNCHEZALVARADO, A. (2005). SMEDWI-2 is a PIWI-like protein that regulates planarian stem cells. Science 310: 1327-30.

REDDIEN, P.W. and SÁNCHEZ-ALVARADO, A. (2004). Fundamentals of planarian regeneration. Annu Rev Cell Dev Bio/20: 725-57.
REUTER, M. and GUSTAFSSON, M.K. (1995). The flatworm nervous system: pattern and phylogeny. EXS 72: 25-59.

REYA, T. and CLEVERS, H. (2005). Whtsignalling in stem cells and cancer. Nature 434: 843-50.

SAITOH, O., YURUZUME, E., WATANABE, K. and NAKATA, H. (1997). Molecular identification of a $G$ protein-coupled receptor family which is expressed in planarians. Gene 195: 55-61.

SAKAI, F., AGATA, K., ORII, H. and WATANABE, K. (2000). Organization and regeneration ability of spontaneous supernumerary eyes in planarians-eye regeneration field and pathway selection by optic nerves-. Zool. Sci. 17: 375381.

SALÓ, E. (2006). The power of regeneration and the stem cells kingdom: The freshwater planarian Schmidtea mediterranea (Platyhelminth). Bioessays 28 546-559.

SALÓ, E. and BAGUÑÀ, J. (1986). Stimulation of cellular proliferation and differentiation in the intact and regenerating planarian Dugesia(G) tigrina by the neuropeptide substance P. J Exp Zoo/237: 129-35.

SALÓ, E. and BAGUÑÀ, J. (2002). Regeneration in planarians and other worms: New findings, new tools, and new perspectives. J Exp Zoo/292: 528-39.

SALÓ, E., MUÑÓZ-MÁRMOL, A.M., BAYASCAS-RAMÍREZ, J.R., GARCÍAFERNÀNDEZ, J., MIRALLES, A., CASALI, A., COROMINAS, M. and BAGUÑÀ J. (1995). The freshwater planarian Dugesia (G) tigrina contains a great diversity of homeobox genes. Hydrobiologia 305: 269-275.

SALÓ, E., PINEDA, D., MARSAL, M., GONZÁLEZ, J., GREMIGNI, V. and BATISTONI, R. (2002). Genetic network of the eye in Platyhelminthes: expression and functional analysis of some players during planarian regeneration. Gene 287: 67-74.

SALÓ, E., TAULER, J., JIMÉNEZ, E., BAYASCAS, J.R., GONZÁLEZ-LINARES, J., GARCÍA-FERNÀNDEZ, J. and BAGUÑÀ, J. (2001). Hox and ParaHox Genes in Flatworms. Characterization and Expression. Amer. Zool. 41: 652-663.

SALVETTI, A., LENA, A., ROSSI, L., DERI, P., CECCHETTINI, A., BATISTONI, R and GREMIGNI, V. (2002). Characterization of DeY1, a novel $Y$-box gene specifically expressed in differentiating male germ cells of planarians. Gene Expr Patterns 2: 195-200.

SÁNCHEZ-ALVARADO, A. (2006). Planarian regeneration: Its end is its begining Cell 124: 241-245.

SÁNCHEZ-ALVARADO, A. and NEWMARK, P.A. (1999). Double-stranded RNA specifically disrupts gene expression during planarian regeneration. Proc Nat/ Acad Sci USA 96: 5049-54.

SÁNCHEZ-ALVARADO, A., NEWMARK, P.A., ROBB, S.M. and JUSTE, R. (2002), The Schmidtea mediterranea database as a molecular resource for studying platyhelminthes, stem cells and regeneration. Development 129: 5659-65.

SATO, K., SHIBATA, N., ORII, H., AMIKURA, R., SAKURAI, T., AGATA, K., KOBAYASHI, S. and WATANABE, K. (2006). Identification and origin of the germline stem cells as revealed by the expression of nanos-related gene in planarians. Dev Growth Differ 48: 615-28.

SHAGIN, D.A., BARSOVA, E.V., BOGDANOVA, E., BRITANOVA, O.V., GURSKAYA, N., LUKYANOV, K.A., MATZ, M.V., PUNKOVA, N.I., USMAN N.Y., KOPANTZEV, E.P. et al. (2002). Identification and characterization of a new family of C-type lectin-like genes from planaria Girardia tigrina. Glycobiology 12: 463-72.

SHIBATA, N., UMESONO, Y., ORII, H., SAKURAI, T., WATANABE, K. and AGATA, K. (1999). Expression of vasa(vas)-related genes in germline cells and totipotent somatic stem cells of planarians. Dev Bio/206: 73-87.

SODERGREN, E., SHEN, Y., SONG, X., ZHANG, L., GIBBS, R.A. and WEINSTOCK G.M. (2006). Shedding genomic light on Aristotle's lantern. Dev Bio/300: 2-8.

STOICK-COOPER, C.L., WEIDINGER, G., RIEHLE, K.J., HUBBERT, C., MAJOR, M.B., FAUSTO, N. and MOON, R.T. (2007). Distinct $W n t$ signaling pathways have opposing roles in appendage regeneration. Development 134: 479-89.

STORNAIUOLO, A., BAYASCAS, J.R., SALÓ, E. and BONCINELLI, E. (1998). A homeobox gene of the orthodenticle family is involved in antero-posterior patterning of regenerating planarians. Int. J. Dev. Biol. 42: 1153-1158.

TETTAMANTI, G., SALÓ, E., GONZÁLEZ-ESTÉVEZ, C., FELIX, A.D., GRIMALDI, A. and DE EGUILEOR, M. (2008).Autophagy in invertebrates:insights into development, regeneration and body remodeling. Current Pharmaceutical Design 14: 116-125. 
THE ENCODE PROJECT CONSORTIUM. (2007). Identification and analysis of functional elements in $1 \%$ of the human genome by the ENCODE pilot project. Nature 447: 799-816.

VENTURINI, G., CAROLEI, A., PALLADINI, G., MARGOTTA, V. and LAURO, M.G. (1983). Radioimmunological and immunocytochemical demonstration of Metenkephalin in planaria. Comp Biochem Physiol C 74: 23-5.

VINSON, J.P., JAFFE, D.B., O'NEILL, K., KARLSSON, E.K., STANGE-THOMANN, N., ANDERSON, S., MESIROV, J.P., SATOH, N., SATOU, Y., NUSBAUM, C. et al. (2005). Assembly of polymorphic genomes: algorithms and application to Ciona savignyi. Genome Res 15: 1127-35.
WANG, Y., ZAYAS, R.M., GUO, T. and NEWMARK, P.A. (2007). nanos function is essential for development and regeneration of planarian germ cells. Proc. Natl. Acad. Sci. USA 104: 5901-5906.

WOLFF, E. and LENDER, T. (1950). Sur le role organisateur du cerveau dans la régénération des yeux chez une planaire d'eau douce. C.R. Acad. SC. 230: 2238-2239.

ZAYAS, R.M., HERNANDEZ, A., HABERMANN, B., WANG, Y., STARY, J.M. and NEWMARK, P.A. (2005). The planarian Schmidtea mediterraneaas a model for epigenetic germ cell specification: analysis of ESTs from the hermaphroditic strain. Proc Nat/ Acad Sci USA 102: 18491-6.

\section{Related, previously published Int. J. Dev. Biol. articles}

See our recent Special Issue Ear Development edited by Fernando Giraldez and Bernd Fritzsch at: http://www.ijdb.ehu.es/web/contents.php?vol=51\&issue=6-7

\section{Characterization of novel genes expressed specifically in the sexual organs of the planarian Dugesia} ryukyuensis

Sumitaka Hase, Emiko Kashiwagi, Kazuya Kobayashi, Motonori Hoshi and Midori Matsumoto Int. J. Dev. Biol. (2007) 51: 345-349

Expression of DjXnp, a novel member of the SNF2-like ATP-dependent chromatin remodelling genes, in intact and regenerating planarians.

Leonardo Rossi, Paolo Deri, Ilaria Andreoli, Vittorio Gremigni, Alessandra Salvetti and Renata Batistoni

Int. J. Dev. Biol. (2003) 47: 293-298

Planarian pharynx regeneration revealed by the expression of myosin heavy chain-A.

Tomoko Sakai, Kentaro Kato, Kenji Watanabe and Hidefumi Orii

Int. J. Dev. Biol. (2002) 46: 329-332

Disto-proximal regional determination and intercalary regeneration in planarians, revealed by retinoic acid induced disruption of regeneration.

R Romero and D Bueno

Int. J. Dev. Biol. (2001) 45: 669-673
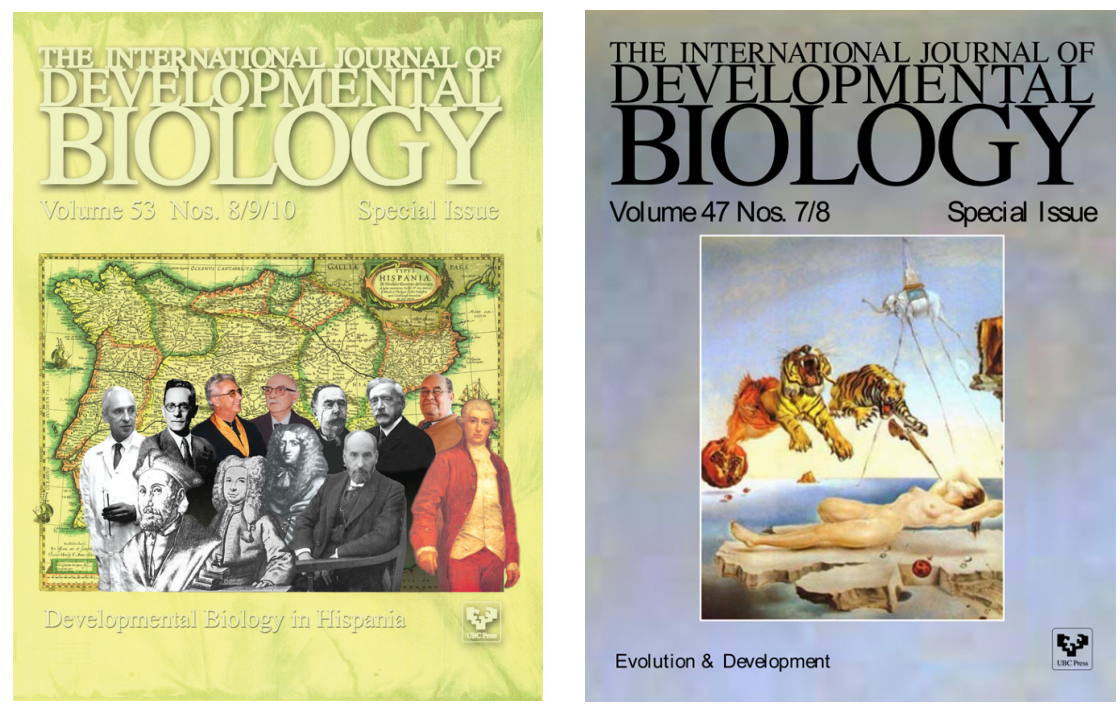

5 yr ISI Impact Factor $(2008)=3.271$ 